\title{
Chapter 24 \\ Connecting Mathematics, Community, Culture and Place: Promise, Possibilities, and Problems
}

\author{
Cynthia Nicol
}

\begin{abstract}
In this essay I explore a critical pedagogy of place for mathematics education. Greenwood's (2013) theoretical framework of a critical pedagogy of place is used alongside frameworks for critical mathematics education to present an approach for connecting mathematics, community, culture and place. Drawing upon literature from both Indigenous and non-Indigenous scholars, theories of place-based education are examined. I introduce theories of mathematics education that advocate what Freire (1970/2000) calls 'problem-posing' practices to read (understand) and write (transform) the world with mathematics Gutstein (2006). Two place-based problems are presented, inspired and used by secondary/middle school teachers in a rural community. These problems provide examples and critiques of connecting mathematics, community, culture, and place. The essay concludes with reflections on the challenges and possibilities of a critical pedagogy of place for mathematics education in a world with increasing complex global issues.
\end{abstract}

Keywords Critical mathematics education - Place-based education Decolonization - Social justice

\subsection{Introduction}

Place-based or community-based education is receiving increased attention as an approach to education that connects school curriculum and local context for better understanding of complex global issues (Cajete 1994; Greenwood 2013; Smith and Sobel 2010; Sobel 1998). Advocating a holistic mindset, place-based education, begins at the local level to inspire student interest, engagement and participation in local community decision making and problem-solving (Smith 2002; Smith and

C. Nicol ( $\square)$

University of British Columbia, 2125 Main Mall, Vancouver, BC V6T 1Z4, Canada

e-mail: cynthia.nicol@ubc.ca

URL: http://edcp.educ.ubc.ca/faculty-staff/cynthia-nicol/

(C) The Author(s) 2018

G. Kaiser et al. (eds.), Invited Lectures from the 13th International Congress

on Mathematical Education, ICME-13 Monographs,

https://doi.org/10.1007/978-3-319-72170-5_24 
Sobel 2010). Thus a curriculum that is grounded in activities and issues of the local place rather than abstractions of the environment, "can help children and youth begin to see themselves as actors and creators rather than observers and consumers" (Smith and Sobel 2010, p. viii). In a world with increasingly complex global issues including economic and social inequities, climate change, poverty, sustainability, resource depletion and mass displacement of people due to war, famine or environmental changes a deep understanding of place is required for understanding "the nature of our relationship with each other and the world" (Gruenewald 2003a, p. 622).

Smith (2002) articulated five different approaches to place-based education: (1) cultural studies involving students in studying local cultural or historical events; (2) nature studies by investigating the physical world; (3) real-world problem solving by locating, reflecting on and developing solutions to local community or school issues; (4) entrepreneurial opportunities by investigating relationships between vocation and place; and (5) participation in community decision-making. In recognizing that conceptions of place-based education ignored critical perspectives on culture, ecology, and schooling, while critical theory ignored attention to place, Gruenewald's (2003b) work adds a sixth approach framed as a "critical pedagogy of place."

In this chapter, I explore the nature of a critical pedagogy of place in the context of mathematics education by asking the question: What would it look like to connect mathematics, community, culture, and place? To answer this question I draw upon research with the Indigenous community of Haida Gwaii in Canada's Pacific northwest to provide a rural example of a critical pedagogy of place. To begin I first explore the nature of critical mathematics education. While some mathematics education scholars theorize and research mathematics education from a critical perspective (e.g., Frankenstein 1987; Gutstein 2012; Kumashiro 2015; Skovsmose 1994), few have explicitly considered the connection and role of place in mathematics education. Following a discussion of critical approaches to mathematics education, I examine theories of place and mathematics education. Next I discuss Greenwood's (2013) critical pedagogy of place drawing upon the processes of decolonization and reinhabitation, and use this framework to critique the case of connecting mathematics, community, culture, and place on Haida Gwaii. I conclude with a discussion of the possibilities and challenges of a critical pedagogy of place in mathematics education.

\subsection{Critical Approaches to Mathematics Education}

More than 30 years ago, Frankenstein, in the United States, writing in English, and Skovsmose, in Denmark, writing in Danish, developed ideas for critical approaches to mathematics education. Frankenstein, who was motivated by the "continuing injustices and the connections among those injustices to deeply entrenched institutional structures" (2012, p. 59), drew upon Freire's (1970/2000) approach to 
developing critical consciousness. She was one of the first to bring Freire's ideas of liberatory problem-posing education into the mathematics classroom (Frankenstein 1987). As critical thinkers, students could "develop their power to perceive critically the way they exist in the world with which and in which they find themselves" (Freire 1970/2000, p. 83). A problem-posing education recognizes people as historical beings with the human desire to move forward, drawing upon the past to improve the future, and accepting incompleteness as the process of "becoming more fully human" (p. 84). Thus a critical education affirmed teaching and learning in a way that both educators and students became teachers and learners, and where the generative themes of students' own historicity became starting places for education.

Frankenstein (1987, 2012), working with Freire's theory, designed statistics lessons for her adult education courses. Students explored problems developed from issues that concerned them, with a focus on unpacking the more hidden purposes and interests in various approaches to statistical analysis along with the contexts of those problems. Frankenstein (1987) provides sample problems for her adult students that were designed to teach mathematics, while raising political and social consciousness. Examples included: examine data on United States military spending or federal subsidies to nuclear power industries and calculate the total spent or total subsidized; examine data on United States food manufacturing to calculate the percentage of firms making the top percentage of net profits; examine decisions made around interest loan payments; examine survey report results; and analyze their own, or other students', mathematical error patterns. Statistics, argues Frankenstein, along with statistical and probability theories, provide rich opportunities for students to critically solve and pose problems related to issues in the public sphere, as well as to question underlying assumptions made based on statistical data and how they are used.

Like Frankenstein, Skovsmose, although working in Denmark, developed a critical approach to mathematics education that is "an open and uncertain concept" (Skovsmose 2012, p. 42) in "an open conceptual landscape" (Skovsmose 2016, p. 2). Critical mathematics education for Skovsmose is a broad field that is best characterized by the issues that drive it. One issue is the performative aspect of mathematics, where mathematics is in action in many different applications and practices including technological design construction, hypothetical reasoning and mathematical modeling, justification or legitimation, realization, and what Skovsmose terms the "dissolution of responsibility" (2011, p. 68). For example, a place of concern for mathematics-based action is mathematical modeling that could be designed to provide legitimacy for a decision that is already made, such as an oil company providing justification to increase its production while limiting environmental impacts. For all forms of mathematics, Skovsmose (2014) argues that "mathematics in action is in need of being carefully criticized" (p. 117).

This is particularly important when mathematics is considered a performative language where the tools of mathematics (its grammar or structure) format what innovations can be developed, how they are used, and the intentions of their use. Using examples from the airline industry Skovsmose (1994) illustrates how mathematics used in technologies for schedules and flight routines becomes "not 
only also descriptive but also prescriptive" (p. 55). Flight routines format or structure our social reality, for instance, in terms of how we might organize or plan our own daily activities. Thus, a critical mathematics education involves students in reflective knowing to become aware of the biases and blind spots, in order to make more apparent this formatting power of mathematics. Skovsmose provides possibilities for the design and implementation of critical mathematics education through using themes or problem-based learning contexts that draw upon students' interests and community experiences. One example of such a project is Economic Relationships in the World of a Child, a series of 12 units challenging young students to engage with mathematics and social issues related to spending pocket money, the child benefit allowance, and what to buy for a youth club. Skovsmose (2011) cautions, however, that although mathematics is in action in many different contexts, such as particular cultural settings, a critical mathematics curriculum needs to consider not only what is familiar to students (i.e., their backgrounds) but also their foregrounds (i.e., their possibilities and obstructions). Finally, at a meta-level, Skovsmose encourages an ongoing critical stance for the idea of critical mathematics education, as mathematics, its purposes, and formatting are neither fixed nor predetermined but continuously changing, and thus "always in need of critique" (2014, p. 119). What role do considerations of place/land have in critical mathematics education?

Gutstein (2006), also inspired by Freire's "problem-posing” curriculum, studied his own teaching of Grade 9 students in an urban American classroom. He extended Freire (1970/2000) ideas of literacy as involving both reading (making sense of the word in the world) and writing (using this sense-making to change the world), to mathematics (Gutstein 2006). Providing examples of projects co-constructed with students, Gutstein writes of challenging his students to read the world mathematically (do and understand mathematics) and write the world mathematically (use that understanding to change the world). One such project focused on using mathematics to understand arguments for recent home foreclosures in the students' community (Gutstein 2012). The mathematics of bank loans, subprime mortgage loans, profits and foreclosures as well as resulting neighbourhood displacement helped students better understand issues they were currently experiencing, and as Gutstein (2012) argues become more engaged in both mathematics and the world. Gutstein suggests that such problems drawing from students' lived experiences or their community knowledge, provide opportunities to learn classical or academic/ school mathematics, as well as engage students in critical inquiry from various perspectives.

Critical approaches to mathematics education developed by Frankenstein, Gutstein and Skovsmose take seriously approaches that draw on students' lived experiences - both their backgrounds and foregrounds - so that students can participate in understanding (reading) and intervening (transforming) the world. For each of these scholars importance is placed on participatory teaching practices that bring student and teacher in reciprocal relationships of co-learning. This means, as Freire (2005) argues, both teachers and students are co-creating, each is at the same time both teaching and learning. In considering place/land in shaping lived 
experiences, Cajete (1994, 2012), an Indigenous Tewa scholar from the United States, refers to this co-learning as an ecology of relationships connecting humans and place in which humans and place shape each other. "People make place" argues Cajete, "as much as place makes them" (1994, p. 84).

\subsection{Theories of Place and Education}

In considering the very idea of place, philosopher Edward Casey (1996), writes that "place is not a mere patch of ground, a bare stretch of earth, a sedentary set of stones" (p. 26). Instead, for Casey, "places not only are, they happen" (p. 27), they are "generative and regenerative," and from place "experiences are born and to it human beings (and other organisms) return for empowerment" (p. 26). Places are living and are lived, they "gather experiences and histories, even languages and thoughts" (p. 24) and places hold them in a kind of gathering action. A place bears on, or structures, the experiences of those (animate and inanimate) within place, while those occupying place organize living with place in a symbiotic co-creation.

Cajete (1994), writing from an Indigenous perspective, suggests that with place we have a dialogical relationship in which we learn more about ourselves, our relationships with each other, and our relationships with the more-than-human world. Place figures prominently in the discourse and life of Indigenous peoples for whom ancestral memories and stories are intimately connected to land and landscapes. Like Casey (1996) who describes place as event, Cajete (1999) conveys the animated nature of place, stating "place is ever evolving and transforming through the life and relationship of all its participants" (p. 193). Place, for Cajete (1999), is "not only a physical place", but also "a spiritual place, a place of being and understanding" where "interactions with places give rise to and define cultures and community" (p. 193).

Similarly, Indigenous scholar Michell et al. (2008) describes place with five dimensions: multidimensionality (more than physical and also emotional); relationality (epistemologically everything is in relation); experientially (experiences in place, on land and in relation to the human and non-human worlds ground meaningful learning); locality (places are specific and general at the same time) and where living place over time brings peoples' "landscapes [to] become reflections of their very souls" (Cajete 2000, p. 183); and land-based (place is land, and relationship between land and people is key). Thus place is described as local, experiential, land-based, and within a holistic perspective that "entails, physical, emotional, and spiritual characteristics" (Michell et al. 2008, p. 27). Bringing place and education together for Indigenous scholars such as Cajete (1999) and Michell (2013) involves considering place/land as teacher in a relational education that recognizes the interdependence of human, other-than-human, and more-than-human worlds toward sustainability, and "reinforces natural connections to land and community" (Cajete 1999, p. 201). 
Place conscious education is the name Greenwood (2013) gives to this meeting of place and education. For Greenwood, place conscious education is a theoretical and philosophical stance that differs from the articulations of place-based education focusing on pedagogical strategies designed to improve student achievement through connections to the community (Smith 2002; Smith and Sobel 2010). Instead, Greenwood (2013) theorizes place conscious education as a critical pedagogy of place consisting of two goals: decolonization and reinhabitation. Greenwood uses decolonization to critique the cultural practices related to place, and reinhabitation to imagine new possibilities of consciousness between people and place. In Greenwood's (2013) words:

\section{Cultural decolonization involves learning to recognize disruption and injury in person-place relationships, and learning to address their causes. ... [D]ecolonization refers also to the educational process of identifying and unlearning patterned and familiar ways of experi- encing and knowing to make room for practices that are unfamiliar. (p. 96)}

Decolonization then involves an "awareness of potential settler impositions, and the desire to reveal and challenge these impositions" (Kerr 2014, p. 86). Coloniality scholars such as Quijano (2007), Fanon (1952/2008), and Memi (1965), examine Euro-centered colonialism as a formal system of domination, social and political, where colonizers' beliefs, knowledge and practices are considered superior to those first occupying place. European colonization, fuelled by the need for resources and materials in the Industrial Era, was one of domination over people, nature, land, and resources. This included political colonization, systematic repression, cultural colonization, and imposed patterns of meaning making. For example, a colonial view of land severs the relationships between humans and place/land, viewing land as something to be tamed, dominated, or conquered. Greenwood's (2013) decolonization then is a personal process of working toward "transforming or resisting oppressive relationships that limit people's ability to control their own life circumstances" (p. 96).

Reinhabitation is the second goal of a critical pedagogy of place. Reinhabitation, writes Greenwood (2013), "involves learning to live well socially and ecologically in a place, and learning to live in a way that does not harm other people and places" (p. 96). Decolonization involves recognition or unlearning colonial practices of dominance and oppression, conscious or unconscious, that could limit renewed relationships. Reinhabitation, on the other hand, involves moving from unlearning to relearning practices of being or inhabiting place that "involves taking a new stance toward one's own being and knowing" (p. 96). 


\subsection{Critical Pedagogy of Place and Mathematics Education}

I am inspired by these views of place and education and argue for their inclusion within the broad field of critical mathematics education. Greenwood (2013) provides a series of questions related to place that I suggest are helpful in considering place and mathematics education as an approach to critical mathematics education. The questions provoke criticality toward the historical, socioecological, and ethical aspects of relations to place that can engage us in the inter-related practices of decolonization and reinhabitation (Greenwood 2013). The dual goals of decolonization and reinhabitation heed Tuck and Yang (2012)'s warning that decolonization as consciousness raising should not be the end goal but instead also require consideration of future actions. Greenwood's (2013, p. 97) critical questions include:

1. What happened here? (historical)

2. What is happening here now and in what direction is the place headed? (socioecological)

3. What should happen here? (ethical)

I bring place and mathematics education together in considering these questions through cases of logging practices and food growing on Haida Gwaii in Canada's Pacific northwest coast.

\subsubsection{Land-Use on Haida Gwaii}

As an example of a critical approach to mathematics education considering place/ land relations, let me turn to an ongoing project located in Canada's Pacific northwest coast-Haida Gwaii, People of the Islands (Nicol et al. 2013; Nicol and Yovanovich 2011, in press). Haida Gwaii is a unique archipelago of over 150 islands located in northern British Columbia's Pacific Ocean, where all places intimately connect people to land and ocean. In fact, a Haida worldview is "everything is connected to everything else"-human, non-human and more-than-human worlds. Before European contact, tens of thousands of people (some Haida Elders say it is many more) lived on and with these islands. Monumental cedar trees, and seafood such as salmon, were resources managed in a sophisticated system of family governance. With European contact also came disease that decimated the Haida population to less than 1000 and required, out of necessity of survival, congregation into two main villages. In 1853 the British claimed Haida Gwaii as British land, and about 25 years later the Canadian government's Indian Act of 1876 declared all "Indians" or First Peoples as under the responsibility of the government, making illegal cultural activities such as the potlatch, used by coastal First Nations in cultural, social, and economic governance 
practices. With ancestral communities displaced or decimated by disease across the Islands the settler colonizer saw most of Haida Gwaii as unsettled and open for resource removal. Whaling stations, open-pit mining, clam canneries, sawmills and logging camps occurred over the years, much without the consultation, permission or decision-making of the Haida people. However, since 1985, the Haida have taken a stand first to logging companies then to the federal government, to reclaim governing rights over their lands. This conflict led to creating the Gwaii Haanas National Park Reserve and an historical agreement where the lands are co-managed by the Government of Canada and the Haida Nation.

Today Haida Gwaii's population is less than 5000, with just less than half the population identifying as having Indigenous ancestry. There is one public school district serving about 500 students, with approximately $70 \%$ identifying as being of Haida or First Nations ancestry. For the past 10 years, I have been working with the school district to explore the nature of creating mathematics education learning environments that are more responsive to the place and community of Haida Gwaii.

As a group that includes community members, Elders, artists, administrators and educators, we are exploring responsive mathematics education. We have co-created a number of lessons that bring mathematics, community, culture, and place together. I discuss two lessons related to land use, one focused on logging, the other on food growing.

\subsubsection{Logging Practices}

Land-use practices on Haida Gwaii can provide a context to critically examine mathematics and connections to place/land. The forests of Haida Gwaii contain an abundance of coniferous trees including red and yellow cedar, hemlock, and sitka spruce, some more than 600 years old. For generations, the Haida have used the bark, wood, and roots of cedar and spruce trees. Cedar was harvested for building magnificent longhouses and ocean-faring canoes; its bark and roots woven into blankets, clothing, baskets, and hats; and its wood carved into house poles and masks that hold ancestral stories. Monumental cedar trees, those over 140 years old and measuring more than $120 \mathrm{~cm}$ in diameter, were carefully selected for harvesting (Council of the Haida Nation 2016). If fallen, the entire tree was used; if left standing, only the bark was stripped in selected sections, preserving the tree's life for future harvests. Cedar trees, like all animate forms, together with the inanimate and spiritual, were considered part of the same world (Stewart 1984). Being part of the forest emanated a life-force. Before European contact the forests of Haida Gwaii and its monumental cedars formed an integral part of Haida life.

Need for aircraft construction grade wood during the early 1900s brought logging practices to Haida Gwaii. Spruce trees on the Islands were superior to elsewhere. With high strength to weight ratio, and tight, straight, uniform grain, Haida Gwaii spruce was perfect for aircraft frames. Heavy industrial clear-cut logging began in the 1950s and increased steadily for the next 40 years (Gowgaia Institute 2007). A mapping animation documenting the logging history from 1901 to 2004 
provides a spatial map of logged areas and a visual representation of the harvesting rate (Gowgaia Institute 2004a).

Since the 1990s, the volume rate of harvest per year has decreased: approximately 2.4 million cubic metres were logged in 1984, 1.8 million cubic metres in 1994, 1.1 million cubic metres in 2004, and 840,000 $\mathrm{m}^{3}$ in 2014 (Council of the Haida Nation 2016). Log barges the size of football fields carry logs off the Islands to Canadian and foreign markets, some carrying close to $30,000 \mathrm{~m}^{3}$ of logs.

Middle school students examine and graph the change in volume harvested over the years. They engage in quantitative reasoning as they explore the relative size of $\log$ volumes, searching for comparable visualizations for 1 million cubic metres. What would hold $1,000,000 \mathrm{~m}^{3}$ ? What else is $1,000,000 \mathrm{~m}^{3}$ in volume? About how many cedar trees make $1,000,000 \mathrm{~m}^{3}$ ? How many log barges were used each year to carry these logs to the mainland? Doing calculations and making referents for large numbers engages students in quantitative reasoning, but it is not sufficient for a critical pedagogy of place.

Asking Greenwood's (2013) historical, socioecological, and ethical questions from a mathematical perspective can lead to critically examining logging practices on Haida Gwaii in terms of who had the decision-making power for which areas would be harvested, how they would harvested, and at what rate. Such a study could call into question the underlying epistemologies of settlers who brought clear-cut logging practices to Haida Gwaii, practices that relegated land as subordinate to settler colonizer needs. How did it come to pass that trees were once logged at a rate of 2.4 million cubic metres per year? In this example, students examine what this rate means. Data documenting logging outputs, in terms of volume of wood harvested and land area logged, could be analyzed to determine how and in what ways rates of harvesting could be sustained or not, as well as who benefits, who does not and in what ways.

Furthermore, the mathematics used in designing the mapping tools used to calculate forest cut-rates could be examined (Gowgaia Institute 2004b). As maps are not neutral-free, students could examine the ways data were collected, represented, analyzed, and communicated, for creating animating maps with consideration of whose perspective is represented. Images of log barges carrying 15,000 tonnes of logs leaving the Islands, clear-cut mountains, and economic benefits can be used to prompt investigation of what is going on here, what is happening now, and what should be happening. Extensions include field trips to the forest scaling yard to learn the process of tree valuation and volume determination. Investigations of questions such as these can engage students in a critical mathematics education, where mathematics is used to make sense of the historical context of logging, current practices, and more sustainable future practices. 


\subsubsection{Food Growing}

Over the past 10 years, sustainable food growing on Haida Gwaii has received increased attention. As an Island system separated from the mainland by large ocean bodies, it is a challenge for food to arrive on Haida Gwaii still fresh and affordable. A two-day drive plus seven to eight hour ferry ride make the price of shipped food to the Islands more than three times that found in mainland cities. For thousands of years, food harvesting of the Haida involved feasting off the range of marine wildlife including ocean fish such as salmon and halibut, shellfish such as clams and crabs, and kelp gathered from vast ocean kelp forests. As more settlers arrived on Haida Gwaii attracted by resource extraction industries such as logging, mining, and fishing, food-harvesting practices changed. Settlers claimed land, but harsh Island climates and short growing seasons challenged attempts to establish farms dedicated to food growing. Many Islanders then became dependent less on local food and more on purchasing food such as meat, fruit, and vegetables imported from the mainland.

With efforts of teachers in northern Haida Gwaii's only high school, and with collaboration and support of the community, a school greenhouse was built on school grounds in 2011. The greenhouse is now one of seven on the Islands and part of a Food-to-Cafeteria system that includes schools and the local hospital. The high school renovated its school kitchen to accommodate the integration of the Food-to-School program using greenhouse food for school cafeteria lunches, and integrating greenhouse activities across the curriculum. As the math and science teacher states:

[D]epending on the course and the potential curricular links to gardening, I have expanded my activities to include full courses specifically dedicated to maintaining school gardens or short visits to the greenhouse for a quick extension linking a particular topic to a hands-on, garden related activity. [high school teacher's written reflection, 2012]

In linking school gardening activities with mathematics, the high school mathematics and science teacher involved students in planning, mapping and designing the shape and size of the raised soil bed boxes to optimize varying natural light intensity, sun angle, and greenhouse temperatures throughout the year. Students mapped garden layout designs, deciding where to seed various plants based on their mature height, light needs, and growth rate. They have studied soil composition and organic composting. Upon food harvesting, students created their own recipes, providing opportunities to study concentration ratios, scaling, volume, and proportion.

Returning to Greenwood's (2013) guiding questions offers an occasion to examine the kinds of activities needed for a critical mathematics education that includes place. Asking 'what happened here?', students and teachers could examine the conditions that led to the need to ship food to Haida Gwaii from the mainland. What forms of traditional marine knowledge or Indigenous knowledge of marine harvesting were practiced? What were the underlying values of these practices, and in what ways were they sustainable? And, what are the underlying values of food 
cultivation, farming, and agriculture? Next, students and teachers could examine socioecological issues that critique the need and use of greenhouse gardens, and the relationship of such food practices to traditional Haida food harvesting. Here students could examine large data sets focused on fish stocks and harvesting rates over various years. Studying patterns of marine harvesting and population growth on the Islands could provide contexts for discussion of socioecological issues of sustainability. Students could also engage in data collection and analysis of interviews and surveys to learn more about who takes advantage of the products of the greenhouse, who does not, and the patterns of food consumption over the year. Finally questions of what should happen could include consideration of further data collected from community members, to learn more about the benefits and possibilities of food-to-school programs, how Indigenous knowledge and harvesting practices are considered and included in current food-work practices, and what an Indigenous 'garden' might actually look like.

The Food-to-School program has gained momentum in Haida Gwaii. School food learning circles were created in 2013-2014, bringing teachers, farmers, Haida Elders, and chefs together to consider possibilities and future goals for the program. It began with settler initiative that is now including the visions and voices of Haida community members.

\subsection{Conclusion: Challenges and Possibilities}

To the conversation of critical mathematics education, I argue for a focus on place, and explore theories of education informed by place. I argue for a broad conceptualization of place, and draw upon historical, socioecological, and ethical questions posed by Greenwood (2013) to consider a critical mathematics education with place in mind. This focus on place differs from place-based education that tends to advocate connections to place in order to motivate and improve student achievement, as well as increase students' connection to places in order to better care for particular places (Smith and Sobel 2010). Certainly student outcomes are important, while pedagogies that re-connect students to places are crucial for rebuilding ecological relationships more globally. However, Indigenous scholars interested in place/land pedagogies push for theorizing land relations that pay attention to settler colonialism as an ongoing and incomplete project. As Cajete (2000) reminds us, places shape ways of being in the world. As first teachers, places represent learning environments that intimately connect human, non-human and more-than-human relational worlds. This is quite different from viewing place as the context for human activity, or background for human privileged use (e.g., resource extractions), or as a material object, or in terms of right of ownership. Such conceptions are what Bang et al. (2014) refer to as "conceptions of place in the service of settler colonial legitimacy" (p. 41). Instead, I am inspired by views of place/land that provide opportunities to challenge such colonial conceptions of land. Greenwood's historical, socioecological, and ethical questions provide one pathway toward a critical 
mathematics education that includes opportunities for increasing awareness of human/land relations, as well as the historical and ongoing colonizing of place.

In conclusion, I discuss the challenges and possibilities of a critical pedagogy of place in mathematics education through the following issues: social action, relevance, the role of mathematics, and urban versus rural places.

\subsubsection{Social Action}

Critical pedagogy conceptualized by Freire, Gutstein, and Frankenstein involves both reading the world with mathematics (using mathematics to understand the world), and writing the world with mathematics (using mathematics to change the world). The land-use lessons provide contexts to engage students in reading and writing the world with mathematics. Mathematics is used to make sense of past and current logging practices, analyze data represented in visual maps (volume of wood/ year) of logging practices, and use of mathematics to examine decisions about sustainability. These are examples of reading the world with mathematics. It is more difficult designing tasks that engage students in writing the world with mathematics. Few examples offered by Gutstein and Peterson (2013) actually involved students in moving from discussions of social action to enacting social action. Currently students on Haida Gwaii are neither participating in challenges to current logging practices, nor are they leading the food-to-school food movement. Both examples stop short of physical action engagement. Nonetheless, mathematics helped students understand the issues associated with each example and provided an occasion for further exploration. One could argue that discussing possibilities for social action could be the first step toward action engagement.

A further challenge related to social action involves considering which action is appropriate. How do teachers and students decide how to act or respond to issues presented? As Esmond (2014) found in her research, it is possible for students to engage in critical mathematics education with a social justice goal that strengthens rather than challenges unjust biases. It is also possible for students to engage in social action that may not change the situation. For example, in the case of logging practices on Haida Gwaii, it is possible that some students whose families are employed in the industry may deepen beliefs of land entitlement that denies Indigenous land claims. It is therefore important for educators to think carefully about problem contexts, be aware of the complexities of a critical pedagogy of place, and be prepared for an open kind of teaching with issues that may not be easily resolved. 


\subsubsection{Relevance}

The land-use lessons were attempts to engage students both in developing mathematics competence and in what Freire (1970/2000) termed critical consciousness. Analyzing land-use and even marine-use practices on Haida Gwaii is a political issue affecting all families on Haida Gwaii in some way. A reason for students' lack of enacted social action in either lesson could rest on the degree of relevance of the issues for students. Freire argues for developing problems based on students' interests-generative themes that are part of students' culture and community. Although both logging and food growing are familiar to students, teachers chose both examples for students. In addition, it could be argued that land use, for example, on Haida Gwaii is not necessarily a topic of interest or of relevance to elementary or secondary school students. While all students on Haida Gwaii are familiar with logging trucks, have friends or family employed in the logging industry, and are witness to the sites of logged areas, most students lack personal experience or expertise in logging. Yet land-use and Indigenous claims to land are of high interest to communities on Haida Gwaii.

In conversations with youth, many spoke about a future need to balance logging, with maintaining old-growth forests, and with sustaining future yields. Nonetheless, the question of relevance is important. Enyedy et al. (2011) researched how, in a culturally relevant mathematics curriculum where students choose an issue to investigate, "different forms of relevance permeate and mediate students' sustained engagement" (p. 275). In a community mapping project these researchers found that relevance for students was negotiated throughout the project. Relevance could focus on mathematics content or context, on authentic purpose such as development of critical consciousness, or on familiar instructional practices. The land-use lessons were guided by relevance focused on content and purpose, where students' local experience and knowledge were considered in the design of the lessons. However, relevance of practices was not considered, and yet could be an important aspect for determining the extent to which students chose to engage or chose not to move toward social action. A critical pedagogy of place in mathematics education is not only about what places are relevant for learning to read and write the world with mathematics, but also about who decides on such relevance

\subsubsection{The Place of Mathematics}

Are problems focused on place somewhat removed from mathematics? Skovsmose (1994) asked himself this question when developing the idea of a critical mathematics education. Teachers discussing the land-use investigations also struggled about the role and place of school mathematics. Teachers often questioned whether or not students' activities were seen as mathematical, and the extent to which the activity met their required curricular outcomes. These concerns are similar to those 
raised by American teachers in Showalter's (2013) study, who questioned whether place-based mathematics education "compromises mathematical rigor" (p. 1). Showalter suggests that maintaining the level of mathematical sophistication appears easier in contexts where problems engage students in statistical analysis. In fact, many of the mathematics lessons offered by Frankenstein $(1987,2012)$, and by Gutstein and Peterson (2013), involve data analysis. This can also be seen in the food growing lessons. Students could analyze data sets on marine life and on harvesting practices as forms of traditional ecological knowledge in contrast to food growing. However, unlike the secondary school teachers in Showalter's study who found it difficult to connect meaningfully with place as a context for mathematical inspiration, the Haida Gwaii teachers could, in the particular cases of land-use, bring the context close to students, partly due to their own experiences with these activities. Nonetheless, I suggest both lessons provide opportunities for teachers and students to engage in mathematical work and to use mathematics to deepen understanding of local and global issues.

\subsubsection{Place as Urban and Rural}

The Haida Gwaii land-use examples were developed in a rural context. Is such work possible in other contexts, for example urban settings? Much of the place-based education research, such as that articulated by Smith and Sobel (2010), has focused on rural contexts, where land and ecological experiences are perhaps more easily accessed than in urban contexts. However, Rubel et al. (2016) argue that working with large data sets on questions of place provides opportunities to examine cities as places of economic and social inequities, providing opportunity for some, and disadvantage for others. Like Enyedy et al. (2011), Rubel et al. (2016) also use participatory mapping as a tool to reveal social injustices through spatial perspectives. Rubel et al. (2016) provide examples of possible investigations of reading and writing the urban context with mathematics. They suggest that the "urban setting is particularly conducive for TMSpJ [Teaching Mathematics for Spatial Justice] and participatory mapping because it is so densely populated and highly wired with cellular and data networks and services" (p. 561). Results from this work indicate that urban students are motivated to engage in critical analysis of place through data analysis and map making. Although there were unexpected outcomes and challenges of this work, students were able to use mathematics to identity issues and question injustices. This work provides evidence that a critical pedagogy of place in mathematics education is possible in not only rural settings such as Haida Gwaii but also urban contexts. 


\subsubsection{Concluding Remarks}

A critical pedagogy of place for mathematics education involves attending to the generative themes of students' experiences to engage students critically with the world through mathematics, and to reason about the world with mathematics. Greenwood's (2013) goals of decolonization and reinhabitation, and his three guiding historical, socioecological, and ethical questions can provide a critical framework for teachers in connecting mathematics, community, culture, and place.

In addition to the challenges noted above, there can be resistance from educators, students, and parents, who question the purpose and place of a mathematics curriculum that has a goal of raising students' critical consciousness. For example, a Canadian news magazine, Maclean's, published an article by Reynolds (2012) titled "Why Are Schools Brainwashing Our Children?", arguing that teachers who are committed to social justice education, mathematics included, fall into the trap of imposing their own biases on students, and are therefore "brainwashing" students in the name of social justice. Reynolds further argues that teaching for social justice deters teachers from their main task of teaching children "properly." Reynolds (2012, para. 17) asks: "[D]oes too much time devoted to social justice divert attention from academic achievement and ironically promote a gross social injustice: students ill-prepared to contend with a complicated and competitive world?" Such a view conveys the message that what is important in mathematics education is successful completion of school mathematics, not politics or culture or learning about, and working for, social justice using mathematics. For some educators and parents, the mathematics classroom should remain pure and focused on school mathematics; for others, the classroom provides opportunities to write the world. The land-use tasks presented provide a counter narrative to Reynolds' claims, as neither teachers nor students came to think in one homogenous perspective. This is not to say, however, that all such tasks provide opportunities for deep conversations of justice that are transformative rather than supportive of further biases.

As we learn more about ways of connecting mathematics, community, culture, and place for a critical pedagogy of place, our understanding of what is possible in terms of teaching for justice will grow. Critical mathematics education with place in mind, I argue, could bring us closer to a vision of "teaching mathematics in a way where it can help us live in harmony with values that protect life and enhance understanding" (Fasheh 2012, p. 103). Or as Gloria Ladson-Billings (2015) states, pursuing "not social justice" but "just justice." 


\section{References}

Bang, M., Curley, L., Kessel, A., Marin, A., Suzukovich, E., \& Strack, G. (2014). Muskrat theories, tobacco in the streets, and living in Chicago as Indigenous land. Environmental Education Research, 1, 37-55.

Cajete, G. (1994). Look to the mountain: An ecology of Indigenous education. Skyland, NC: Kivaki Press.

Cajete, G. (1999). Reclaiming biophilia: Lessons from Indigenous peoples. In G. Smith \& D. Williams (Eds.), Ecological education in action: On weaving education, culture, and the environment (pp. 189-206). Albany, New York: State University of New York Press.

Cajete, G. (2000). Native science: Natural laws of interdependence. Santa Fe, New Mexico: Clearlight Publishers.

Cajete, G. (2012). Contemporary Indigenous education: Thoughts for American Indian education in a 21 st-century world. In S. Mukhopadhyay \& W. M Roth, (Eds.), Alternative forms of knowing (in) mathematics: Celebrations of diversity of mathematical practices (pp. 33-51). Rotterdam, The Netherlands: Sense.

Casey, E. (1996). How to get from space to place. In S. Feld \& K. Basso (Eds.), Senses of place (pp. 13-52). Sante Fe, New Mexico: School of American Research Press.

Council of the Haida Nation. (2016). Forest form 2016. http://www.haidanation.ca/. Accessed February 10, 2017.

Enyedy, N., Joshua, D., \& Fields, D. (2011). Negotiating the 'relevant' in culturally relevant mathematics. Canadian Journal of Science, Mathematics and Technology Education, 11(3), 273-291.

Esmond, I. (2014). 'Nobody's rich and nobody's poor...it sounds good, but it's actually not': Affluent students learning mathematics and social justice. The Journal of the Learning Sciences, 23, 348-391.

Fanon, F. (1952/2008). Black skin, white masks. New York, NY: Grove Press.

Fasheh, M. (2012). The role of mathematics in the destruction of communities, and what we can do to reverse this process, including using mathematics. In O. Skovsmose \& B. Greer (Eds.), Opening the cage: Critique and politics of mathematics education (pp. 93-106). Rotterdam, The Netherlands: Sense.

Frankenstein. M. (1987). Critical mathematics education: An application of Paulo Freire's epistemology. In I. Shor (Ed.), Freire for the classroom: A sourcebook for liberatory teaching (pp. 180-210). Portsmouth, NH: Heinemann.

Frankenstein, M. (2012). Beyond math content and process: Proposals for underlying aspects of social justice education. In A. Wager \& D. Stinson (Eds.), Teaching mathematics for social justice: Conversations with educators (pp. 49-62). Reston, VA: National Council of Teachers of Mathematics.

Freire, P. (1970/2000). Pedagogy of the oppressed. New York, NY: Bloomsbury.

Freire, P. (2005). Teachers as cultural workers: Letters to those who dare teach. Boulder, CO: Westview Press.

Gowgaia Institute. (2004a). Logging Haida Gwaii 1901-2004. SpruceRoots. http://www. spruceroots.org/LogVideo/LogVid.html. Accessed February 10, 2017.

Gowgaia Institute. (2004b). Logging Haida Gwaii. SpruceRoots. http://www.spruceroots.org/ Maps/Logging.html. Accessed February 10, 2017.

Gowgaia Institute. (2007). Old growth forest condition and distribution. SpruceRoots. http://www. spruceroots.org/Booklets/Booklet.html. Accessed February 10, 2017.

Greenwood, D. (2013). A critical theory of place-conscious education. In R. Stevenson, M. Brody, J. Dillon, \& A. Wals (Eds.), International handbook of research on environmental education (pp. 93-100). New York: Routledge. https://doi.org/10.4324/9780203813331. 
Gruenewald, D. (2003a). Foundations of place: A multidisciplinary framework for place-conscious education. American Educational Research Journal, 40(3), 619-654.

Gruenewald, D. (2003b). The best of both worlds: A critical pedagogy of place. Educational Researcher, 32(4), 3-12.

Gutstein, E. (2006). Reading and writing the world with mathematics: Toward a pedagogy for social justice. New York, NY: Routledge.

Gutstein, E. (2012). Connecting community, critical and classical knowledge in teaching mathematics for social justice. In S. Mukhopadhyay \& W. M Roth, (Eds.), Alternative forms of knowing (in) mathematics: Celebrations of diversity of mathematical practices (pp. 299-312). Rotterdam, The Netherlands: Sense.

Gutstein, E., \& Peterson, B. (2013). Rethinking mathematics: Teaching social justice by the numbers. Milwaukee, Wisconsin: Rethinking Schools.

Kerr, J. (2014). Western epistemic dominance and colonial structures: Considerations for thought and practice in programs of teacher education. Decolonization: Indigeneity, Education \& Society, 3, 83-104.

Kumashiro, K. K. (2015). Against common sense: Teaching and learning toward social justice. New York, NY: Routledge.

Ladson-Billings, G. (2015). Social justice in education award lecture. American Educational Research Association. https://www.youtube.com/watch?v=ofB_tloTYhI. Accessed June 15, 2017.

Memi, A. (1965). The colonizer and the colonized. Boston, MA: Beacon Press.

Michell, H. (2013). Cree ways of knowing and school science. Vernon, BC, Canada: J Charlton Publishing.

Michell, H., Vizina, Y., Augustus, C., \& Sawyer, J. (2008). Learning Indigenous science from place: Learning Indigenous science from place research study examining indigenous-based science perspectives in Saskatchewan first nations and métis community contexts. University of Saskatchewan Aboriginal Education Research Centre, desLibris-Documents, \& Canadian Electronic Library. Aboriginal Education Research Centre.

Nicol, C., Archibald, J., \& Baker, J. (2013). Designing a model of culturally responsive mathematics education: Place, relationships and storywork. Mathematics Education Research Journal, 25(1), 73-89.

Nicol, C., \& Yovanovich, J. (2011). Tluuwaay 'Waadluxan: Mathematical adventures. Skidegate, BC: Haida Gwaii School District 50.

Nicol, C., \& Yovanovich, J. (in press). Sustaining living and learning culturally responsive pedagogy. In J. Archibald \& J. Hare (Eds.), Learning, knowing, sharing: Celebrating successes in K-12 Aboriginal education in British Columbia. British Columbia Principals' \& Vice-Principals' Association.

Quijano, A. (2007). Coloniality and modernity/rationality. Cultural Studies, 21, 168-178.

Reynolds, C. (2012). Why are schools brainwashing our children? Maclean's, 125(43). http:// www.macleans.ca/news/canada/why-are-schools-brainwashing-our-children/. Accessed June $15,2017$.

Rubel, L., Hall-Wieckert, M., \& Lim, V. (2016). Teaching mathematics for spatial justice: Beyond a victory narrative. Harvard Educational Review, 86(4), 556-579.

Showalter, D. (2013). Place-based mathematics education: A conflated pedagogy? Journal of Research in Rural Education, 28(6), 1-13.

Skovsmose, O. (1994). Towards a philosophy of critical mathematics education. Dordrecht, The Netherlands: Kluwer Academics Publishers.

Skovsmose, O. (2011). An invitation to critical mathematics education. Rotterdam, The Netherlands: Sense.

Skovsmose, O. (2012). Critical mathematics education: A dialogical journey. In A. Wager \& D. Stinson (Eds.), Teaching mathematics for social justice: Conversations with educators (pp. 3547). Reston, VA: National Council of Teachers of Mathematics. 
Skovsmose, O. (2014). Critical mathematics education. In S. Lerman (Ed.), Encyclopedia of mathematics education (pp. 116-120). Dordrecht: Springer Science+Business Media. https:// doi.org/10.1007/978-94-007-4978-8.

Skovsmose, O. (2016). What could critical mathematics education mean for different groups of students? For the Learning of Mathematics, 36(1), 2-7.

Smith, G., \& Sobel, D. (2010). Place-and community-based education in schools. New York, NY: Routledge.

Smith, G. A. (2002). Place-based education: Learning to be where we are. Phi Delta Kappan, 83, 584-594.

Sobel, D. (1998). Mapmaking with children. Portsmouth, NH: Heinemann.

Steward, H. (1984). Cedar. Vancouver, BC: Douglas \& McIntyre.

Tuck, E., \& Yang, K. (2012). Decolonization is not a metaphor. Decolonization: Indigeneity, Education \& Society, 1, 1-40.

Open Access This chapter is licensed under the terms of the Creative Commons Attribution 4.0 International License (http://creativecommons.org/licenses/by/4.0/), which permits use, sharing, adaptation, distribution and reproduction in any medium or format, as long as you give appropriate credit to the original author(s) and the source, provide a link to the Creative Commons license and indicate if changes were made.

The images or other third party material in this chapter are included in the chapter's Creative Commons license, unless indicated otherwise in a credit line to the material. If material is not included in the chapter's Creative Commons license and your intended use is not permitted by statutory regulation or exceeds the permitted use, you will need to obtain permission directly from the copyright holder. 